Nat Chem Biol. 2008 October ; 4(10): 599-601. doi:10.1038/nchembio.110.

\title{
Mechanism of $\mathrm{Cu}_{\mathrm{A}}$ assembly
}

\author{
Luciano A Abriata $^{1,2}$, Lucia Banci ${ }^{2}$, Ivano Bertini ${ }^{2}$, Simone Ciofi-Baffoni ${ }^{2}$, Petros \\ Gkazonis $^{2,3}$, Georgios A Spyroulias ${ }^{3}$, Alejandro J Vila ${ }^{1}$, and Shenlin Wang ${ }^{2}$ \\ 1 Instituto de Biología Molecular y Celular de Rosario, Consejo Nacional de Investigaciones Científicas y \\ Técnicas, Facultad de Ciencias Bioquímicas y Farmacéuticas, Universidad Nacional de Rosario, Suipacha \\ 531, (S2002LRK) Rosario, Argentina.
}

2Magnetic Resonance Center CERM and Department of Chemistry, University of Florence, Scientific Campus, 50019, Sesto Fiorentino, Florence, Italy.

3Department of Pharmacy, University of Patras, Panepistimioupoli-Rion, GR-26504 Patras, Greece.

\begin{abstract}
Copper is essential for proper functioning of cytochrome $c$ oxidases, and therefore for cellular respiration in eukaryotes and many bacteria. Here we show that a new periplasmic protein $\left(\mathrm{PCu}_{\mathrm{A}} \mathrm{C}\right)$ selectively inserts $\mathrm{Cu}(\mathrm{I})$ ions into subunit II of Thermus thermophilus $b a_{3}$ oxidase to generate a native $\mathrm{Cu}_{\mathrm{A}}$ site. The purported metallochaperone Sco1 is unable to deliver copper ions; instead, it works as a thiol-disulfide reductase to maintain the correct oxidation state of the $\mathrm{Cu}_{\mathrm{A}}$ cysteine ligands.
\end{abstract}

$\mathrm{Cu}_{\mathrm{A}}$ is a dinuclear copper site within the soluble domain of subunit II (Cox2) of bacterial and eukaryotic cytochrome $c$ oxidases $(\mathrm{CcOs})$, whose function is to convey electrons from a soluble cytochrome $c$ to the catalytic heme $a_{3}-\mathrm{Cu}_{\mathrm{B}}$ center of $\mathrm{CcO}$ (refs. 1,2). The proper assembly of the $\mathrm{Cu}_{\mathrm{A}}$ site is essential for the catalytic machinery of a functional oxidase. Several proteins have been identified as key players in the delivery of metal ions to the $\mathrm{Cu}_{\mathrm{A}}$ site3, but the detailed molecular mechanisms and the specific roles of each protein are poorly understood 4 . In prokaryotes two protein families have been proposed to be involved in $\mathrm{Cu}_{\mathrm{A}}$ site formation. The first includes proteins that are able to bind $\mathrm{Cu}(\mathrm{I})$ through methionine and histidine residues arranged in a highly conserved $\mathrm{H}(\mathrm{M}) \mathrm{X}_{10} \mathrm{MX}_{21} \mathrm{HXM}$ motif 5 (referred to as periplasmic $\mathrm{Cu}_{\mathrm{A}}$ chaperone $\left(\mathrm{PCu}_{\mathrm{A}} \mathrm{C}\right)$ hereafter). The second consists of the Sco proteins, whose mechanism of action in $\mathrm{Cu}_{\mathrm{A}}$ assembly as thioredoxins or metallochaperones is still debated6. These proteins $\left(\mathrm{PCu}_{\mathrm{A}} \mathrm{C}\right.$ and $\left.\mathrm{Sco}\right)$ are often found in the same bacterial operon, and most of the identified operons that encode Sco also contain a gene for $\operatorname{Cox} 2$ (ref. 7). $\mathrm{PCu}_{\mathrm{A}} \mathrm{C}$ and Sco proteins occur together in the Vibrio cholerae bacterium (http://string.embl.de).

The $\mathrm{Cu}_{\mathrm{A}}$-containing subunit II from Thermus thermophilus $b a_{3}$ oxidase $\left(T t \mathrm{Cu}_{\mathrm{A}}\right.$ hereafter), $T$. thermophilus $\mathrm{PCu}_{\mathrm{A}} \mathrm{C}\left(T t \mathrm{PCu}_{\mathrm{A}} \mathrm{C}\right)$ and $T$. thermophilus Sco1 (Tt Sco1), which are all located in the bacterial periplasm, were expressed as truncated soluble versions in which the transmembrane helices (and the signal peptide region in $T t \mathrm{PCu}_{\mathrm{A}} \mathrm{C}$ ) were not included, thus

Correspondence should be addressed to I.B. (ivanobertini@cerm.unifi.it). AUTHOR CONTRIBUTIONS

L.A.A. cloned and expressed $T t \mathrm{Sco} 1$ and $T t \mathrm{Cu}_{\mathrm{A}}$ proteins and contributed to the NMR structure of $T t$ Scol and NMR titrations; P.G. cloned and expressed $\mathrm{PCu}_{\mathrm{A}} \mathrm{C}$ protein and performed redox experiments; S.W. solved the structures of $\mathrm{PCu}_{\mathrm{A}} \mathrm{C}$ and contributed to the NMR titrations and NMR structure of $T t$ Sco1; S.C.-B. supervised and coordinated the acquisition of NMR data and structures, and the performance of titration experiments; I.B., L.B., G.A.S. and A.J.V. developed and directed the project and contributed to the writing. All authors were involved in the discussion of the biochemical meaning of the experiments.

Published online at http://www.nature.com/naturechemicalbiology/

Reprints and permissions information is available online at http://npg.nature.com/reprintsandpermissions/ 
resulting in constructs of 136,172 and 121 amino acids, respectively (Supplementary Methods and Supplementary Fig. 1 online).

$T t \mathrm{PCu}_{\mathrm{A}} \mathrm{C}$ binds one equivalent of $\mathrm{Cu}(\mathrm{I})$, as also observed for the homologous protein DR1885 (ref. 5). The $\mathrm{Cu}$ (I) binding affinity, measured by competition experiments with DTT followed by ${ }^{1} \mathrm{H}_{-}{ }^{15} \mathrm{~N}$ HSQC, is $(2.2 \pm 0.1) \times 10^{-13} \mathrm{M}$ (Supplementary Fig. 2, Supplementary Data and Supplementary Methods online). Upon addition of $\mathrm{Cu}(\mathrm{I})$ up to a 1:1 metal/protein ratio, the most affected region includes residues His46, Met61, Met83 and His85 and the neighboring residues (Supplementary Fig. 2), thus defining the copper binding ligands (similar to the Met $_{3}$ His ligand set found for DR1885 in homologous positions).

Sco proteins, in contrast to the $T t \mathrm{PCu}_{\mathrm{A}} \mathrm{C}$ protein family, are able to bind both $\mathrm{Cu}(\mathrm{I})$ and $\mathrm{Cu}$ (II) ions8-10. $\mathrm{Cu}(\mathrm{I})$ binding followed by NMR confirmed the involvement of metal ligands conserved in all Sco1 proteins (Cys47, Cys51 and His137) (Supplementary Fig. 2 and Supplementary Data). Apo-Tt Sco1 showed weaker Cu(I) binding capabilities compared with its eukaryotic homologs (a lower limit of $\sim 10^{-10} \mathrm{M}$ was estimated for the $K_{\mathrm{d}}$ of Cu(I)-Tt Sco1). $\mathrm{Cu}$ (II)-Tt Sco1 presents spectroscopic features resembling those of the human and Bacillus subtilis homologs8,10,11 (Supplementary Data and Supplementary Fig. 3 online).

The solution structures of apo-Tt $\mathrm{PCu}_{\mathrm{A}} \mathrm{C}, \mathrm{Cu}(\mathrm{I})-\mathrm{Tt} \mathrm{PCu}_{\mathrm{A}} \mathrm{C}$ and apo-Tt Sco1 were determined using NMR-derived restraints (Supplementary Methods). The NMR spectra of apo- and $\mathrm{Cu}$ (I) $-T t \mathrm{PCu}_{\mathrm{A}} \mathrm{C}$ variants show two sets of signals in a 65:35 ratio (Supplementary Fig. 3) for 23 and 24 residues, respectively, which originate from a cis-trans isomerization of the Gly13Pro14 peptide bond. The two structures resulting from this isomerism in both apo- and $\mathrm{Cu}(\mathrm{I})-$ $T t \mathrm{PCu}_{\mathrm{A}} \mathrm{C}$ were obtained (Fig. 1a-d and Supplementary Tables 1 and 2 online). The structural differences induced by this isomerization are localized in loops 1 and 8 and do not affect $\mathrm{Cu}$ (I) binding (Fig. 1a-d). Tt $\mathrm{PCu}_{\mathrm{A}} \mathrm{C}$ is arranged in a cupredoxin-like fold (Fig. 1a-d), except that strands $\mu 4$ and $\mu 5$ form an extended, flexible solvent-exposed $\mu$-hairpin that is longer than the one reported for the homologous DR1885 protein5. The $\mathrm{Cu}(\mathrm{I})$ ion is coordinated in a tetrahedral arrangement to the sulfur atoms of Met61 and Met85, the $\mathrm{N} \delta 1$ atom of His46 and the N\&2 atom of His83 (Fig. 1a,c). The structure of apo-Tt Sco1 in the reduced form adopts the thioredoxin-like fold already observed for all Sco1 homologs12-16 (Fig. 1e and Supplementary Table 3 online). Loop 8 (which includes the metal ligand His137) adopts an extended conformation in $T t$ Sco1 (Fig. 1e) resembling that observed for the human and yeast proteins, in contrast with the shorter (and less extended) loop 8 present in Bs Sco1. The cysteine metal ligands are solvent exposed (as in other Sco1 proteins), which is in agreement with the observation of rapid air oxidation.

The availability of the NMR resonance assignments of the apo and the metallated forms of the two possible copper donors, as well as that of the $\mathrm{Cu}_{\mathrm{A}}$-containing soluble fragment of the $T$. thermophilus $b a_{3}$ oxidase, allowed us to investigate, through NMR, copper uptake by the $\mathrm{Cu}_{\mathrm{A}}$ fragment. We simultaneously monitored the occurrence of copper transfer and the formation of the correct metallated form, and also identified the copper donor protein, by detecting the resulting apo state of the protein that had transferred the copper ions. This strategy also allows the identification of possible transient intermediates.

Addition of $\mathrm{Cu}(\mathrm{I})$ to reduced ${ }^{15} \mathrm{~N}$ apo- $T t \mathrm{Cu}_{\mathrm{A}}$ under anaerobic conditions gives rise to the fully metallated protein in the reduced state (Supplementary Data and Supplementary Fig. 4 online). Exposure of this species to oxygen resulted in the formation of a purple species with the characteristic electronic spectrum and ${ }^{1} \mathrm{H}$ NMR signals of the oxidized, mixed-valence $\mathrm{Cu}_{\mathrm{A}}$ center (Supplementary Fig. 4)17. This indicates that the $\mathrm{Cu}_{\mathrm{A}}$ center can be formed in vitro without the assistance of any protein when the cysteine residues of the $\mathrm{Cu}_{\mathrm{A}}$ center are reduced. The affinity of both copper ions in $T t \mathrm{Cu}_{\mathrm{A}}$ is in the femtomolar range based on competition 
studies with DTT (Supplementary Methods) and is thus higher than that of $T t \mathrm{PCu}_{\mathrm{A}} \mathrm{C}$ and $T t$ $\mathrm{Sco} 1$. However, because $\mathrm{Cu}(\mathrm{I})$ is not freely available in the periplasmic space, a $\mathrm{Cu}(\mathrm{I})$ chaperone is needed to deliver two $\mathrm{Cu}(\mathrm{I})$ ions to the apo- $\mathrm{Cu}_{\mathrm{A}}$ protein.

We initially explored the possible role of $\mathrm{Sco} 1$ as a $\mathrm{Cu}(\mathrm{I})$ or $\mathrm{Cu}(\mathrm{II})$ donor to apo- $\mathrm{Cu}_{\mathrm{A}}$. No evidence of copper uptake by the $\mathrm{Cu}_{\mathrm{A}}$ protein or of metal depletion of $T t \mathrm{Sco} 1$ was observed, which suggests that $T t \mathrm{Sco} 1$ is not responsible for the direct delivery of $\mathrm{Cu}(\mathrm{I})$ or $\mathrm{Cu}(\mathrm{II})$ ions into apo- $T t \mathrm{Cu}_{\mathrm{A}}$.

Genomic studies have suggested that $T t \mathrm{PCu}_{\mathrm{A}} \mathrm{C}$ homologs could be involved in copper transport in the periplasmic space of bacteria5,18, and we decided to test this previously unexplored hypothesis. When apo-Tt $\mathrm{Cu}_{\mathrm{A}}$ was added to a solution of ${ }^{15} \mathrm{~N} \mathrm{Cu}(\mathrm{I})-T t \mathrm{PCu}_{\mathrm{A}} \mathrm{C}$, a new set of resonances corresponding to apo-Tt $\mathrm{PCu}_{\mathrm{A}} \mathrm{C}$ was observed (Fig. 2a). A step-wise titration led to the progressive disappearance of the signals corresponding to $\mathrm{Cu}(\mathrm{I})-T t \mathrm{PCu}_{\mathrm{A}} \mathrm{C}$, with the concomitant increase of signals from the apo form (Fig. 2a). This process was complete at a $T t \mathrm{Cu}_{\mathrm{A}} / T t \mathrm{PCu}_{\mathrm{A}} \mathrm{C}$ ratio of 1:2 (Fig. 2a). The complementary experiment to characterize the metallated species was performed by adding two equivalents of unlabeled $\mathrm{Cu}(\mathrm{I})-T t \mathrm{PCu}_{\mathrm{A}} \mathrm{C}$ to ${ }^{15} \mathrm{~N}$ apo- $T t \mathrm{Cu}_{\mathrm{A}}$, which led to the typical ${ }^{1} \mathrm{H}_{-}{ }^{15} \mathrm{~N}$ HSQC pattern of native $\mathrm{Cu}(\mathrm{I})_{2}-T t \mathrm{Cu}_{\mathrm{A}}$ (Fig. 2b). A step-wise titration disclosed the formation of an intermediate species when less than one equivalent of $\mathrm{Cu}(\mathrm{I})-T t \mathrm{PCu}_{\mathrm{A}} \mathrm{C}$ was added to the $\mathrm{Cu}_{\mathrm{A}}$ domain (Fig. 2b,c). This species then converted into the dimetallated $\mathrm{Cu}(\mathrm{I}) 2-T t \mathrm{Cu}_{\mathrm{A}}$ upon further addition of the donor protein (Fig. 2c). This intermediate species displayed resonances with chemical shifts differing from those of both the apo- and the fully metallated species (Fig. 2b), and it did not show any line broadening with respect to the other forms of the $\mathrm{Cu}_{\mathrm{A}}$ domain. This behavior, together with the observation that no intermediate was identified by monitoring the copper release from $\mathrm{Cu}$ (I) $-T t \mathrm{PCu}_{\mathrm{A}} \mathrm{C}$ to apo- $T t \mathrm{Cu}_{\mathrm{A}}$, allowed us to rule out the detection of a possible complex between the two proteins, and suggested that this intermediate corresponds to a singly metallated $\mathrm{Cu}_{\mathrm{A}}$ species. We conclude that $T t \mathrm{PCu}_{\mathrm{A}} \mathrm{C}$ is capable of transferring two $\mathrm{Cu}(\mathrm{I})$ ions to the reduced apo-Tt $\mathrm{Cu}_{\mathrm{A}}$ site sequentially, thereby eliciting the formation of the binuclear $\mathrm{Cu}_{\mathrm{A}}$ center in the reduced state (Fig. 2c). Aerobic oxidation of this mixture leads to the mixed-valence, oxidized $\mathrm{Cu}_{\mathrm{A}}$ center, as revealed by its characteristic electronic spectrum (Supplementary Fig. 4).

$\mathrm{Sco} 1$ is able to bind $\mathrm{Cu}(\mathrm{II})$ ions. The possible direct transfer of $\mathrm{Cu}(\mathrm{II})$ ions was explored by following the titration of a sample of ${ }^{15} \mathrm{~N}$-labeled $\mathrm{Cu}(\mathrm{II})-T t$ Sco1 with unlabeled apo- $T t \mathrm{Cu}_{\mathrm{A}}$. There was no evidence of the formation of apo-Tt Scol in the ${ }^{1} \mathrm{H}_{-}{ }^{15} \mathrm{~N}$ HSQC spectra, thus revealing the inability of this protein to transfer $\mathrm{Cu}$ (II) ions to the $\mathrm{Cu}_{\mathrm{A}}$ domain. When 2 equivalents of unlabeled $\mathrm{Cu}(\mathrm{I})-T t \mathrm{PCu}_{\mathrm{A}} \mathrm{C}$ were added to the mixture of ${ }^{15} \mathrm{~N}$-labeled $\mathrm{Cu}(\mathrm{II})-$ $T t \mathrm{Sco} 1$ and ${ }^{15} \mathrm{~N}$-labeled apo- $T t \mathrm{Cu}_{\mathrm{A}}$, the reduced $\mathrm{Cu}(\mathrm{I})_{2}-T t \mathrm{Cu}_{\mathrm{A}}$ center was formed (Supplementary Fig. 5 online). This result indicates that (i) the presence of $\mathrm{Cu}(\mathrm{II})-T t \mathrm{Sco} 1$ does not prevent $\mathrm{Cu}(\mathrm{I})-T t \mathrm{PCu}_{\mathrm{A}} \mathrm{C}$ from transferring $\mathrm{Cu}(\mathrm{I})$, and (ii) as the final product is the reduced $\mathrm{Cu}(\mathrm{I})_{2}-T t \mathrm{Cu}_{\mathrm{A}}$ center, the mechanism cannot involve the concerted action of both $\mathrm{Cu}$ (II)-Tt $\mathrm{Sco} 1$ and $\mathrm{Cu}(\mathrm{I})-T t \mathrm{PCu}_{\mathrm{A}} \mathrm{C}$, which would give rise to a mixed-valence, oxidized $\mathrm{Cu}_{\mathrm{A}}$ site.

Sco1, which has already been shown to be essential for copper upload into the $\mathrm{Cu}_{\mathrm{A}}$ site in $B$. subtilis 19 , is characterized by a thioredoxin-like fold. We therefore investigated the possible thiol-disulfide oxidoreductase activity of $T t$ Scol during copper uptake. Oxidized apo- $T t$ $\mathrm{Cu}_{\mathrm{A}}$, in which the two cysteine ligands had been aerobically oxidized to form a disulphide bond (ox-apo-Tt $\mathrm{Cu}_{\mathrm{A}}$ hereafter), was not able to bind copper ions when $\mathrm{Cu}(\mathrm{I})-T t \mathrm{PCu}_{\mathrm{A}} \mathrm{C}$ was added. However, when ${ }^{15} \mathrm{~N}$-labeled ox-apo- $T t \mathrm{Cu}_{\mathrm{A}}$ was titrated with a 2:1 mixture of $\mathrm{Cu}(\mathrm{I})-$ $T t \mathrm{PCu}_{\mathrm{A}} \mathrm{C}$ and reduced apo-Tt $\mathrm{Sco} 1$, the backbone resonances of the native $\mathrm{Cu}(\mathrm{I})_{2}-T t \mathrm{Cu}_{\mathrm{A}}$ appeared (Fig. 3a). Exposure of the reaction sample to atmospheric oxygen allowed the development of the typical UV-vis spectrum of the oxidized, mixed-valence $\mathrm{Cu}_{\mathrm{A}}$ center, which 
confirmed that the native site had formed. A 4-acetamide-4'- amleimidylstilbene-2,2'disulfonic acid, disodium salt (AMS)-reacted SDS gel of the reaction mixture (run under nonreducing conditions, Supplementary Methods) indicated that, at a $T t \mathrm{Cu}_{\mathrm{A}} / T t \mathrm{Sco} 1 / T t$ $\mathrm{PCu}_{\mathrm{A}} \mathrm{C}$ ratio of 1:1:2, $T t$ Sco1 is mostly in the oxidized state (Fig. 3b). Similarly, in a 1:1 Tt $\mathrm{Cu}_{\mathrm{A}} / T t$ Sco1 mixture, $T t$ Sco1 is essentially in an oxidized state, whereas $T t \mathrm{Cu}_{\mathrm{A}}$ is in a reduced state (Fig. 3b). These experiments show that $T t$ Sco1 is able to reduce the disulfide bond of oxapo- $T t \mathrm{Cu}_{\mathrm{A}}$ protein, which demonstrates that this protein behaves as a thiol-disulfide reductase in in vitro $\mathrm{Cu}_{\mathrm{A}}$ assembly.

Although it is possible that the in vivo pathway is more complex, the structural characterization of $T t \mathrm{PCu}_{\mathrm{A}} \mathrm{C}$ and of its copper binding properties and its ability to selectively and sequentially deliver two $\mathrm{Cu}(\mathrm{I})$ ions to apo-Tt $\mathrm{Cu}_{\mathrm{A}}$, thus giving rise to the native $\mathrm{Cu}(\mathrm{I})_{2}-T t \mathrm{Cu}_{\mathrm{A}}$ site in vitro, strongly supports the annotation of this protein as a periplasmic $\mathrm{Cu}(\mathrm{I})$ chaperone. Our data also indicate that $T t$ Scol is able to reduce the disulfide bond of the $\mathrm{Cu}_{\mathrm{A}}$ center, thus allowing the $\mathrm{Cu}_{\mathrm{A}}$ site to accept $\mathrm{Cu}(\mathrm{I})$ ions from $T t \mathrm{PCu}_{\mathrm{A}} \mathrm{C}$. The mechanism of bacterial $\mathrm{Cu}_{\mathrm{A}}$ assembly therefore consists of a sequential insertion of two $\mathrm{Cu}(\mathrm{I})$ ions donated by a metallochaperone once the disulfide bond of the $\mathrm{Cu}_{\mathrm{A}}$ center is reduced by a thioredoxin. In eukaryotes the assembly of the $\mathrm{Cu}_{\mathrm{A}}$ site is different, as Scos have a larger affinity for $\mathrm{Cu}(\mathrm{I})$ and may act as both chaperones and thioredoxins 12,20-22.

\section{Supplementary Material}

Refer to Web version on PubMed Central for supplementary material.

\section{ACKNOWLEDGMENTS}

This work was supported by the European Commission (European Network of Research Infrastructures for Providing Access and Technological Advancements in Bio-NMR contract $n^{\circ}$ 026145, SPINE2-Complexes contract $\mathrm{n}^{\circ}$ LSHGCT-2006-031220 and Marie Curie host fellowships for early stage research training $\mathrm{n}^{\circ}$ MEST-CT-2004-504391, NMR in Inorganic Structural Biology) and by a grant from Ente Cassa di Risparmio di Firenze. Work in Rosario (Argentina) was supported by the US National Institutes of Health (R01-GM068682), the Howard Hughes Medical Institute and Agencia Nacional de Promoción Científica y Tecnoló gica (PME2003-0026 and PICT2002-01-11625) grants to A.J.V. L.A.A. thanks Consejo Nacional de Investigaciones Científícas y Técnicas for a doctoral fellowship. We thank D. Winge (Departments of Medicine and Biochemistry, University of Utah Health Sciences Center, University of Utah) for kindly providing the expression plasmid for $T t$ Sco1.

\section{References}

1. Ostermeier C, Iwata S, Michel H. Curr. Opin. Struct Biol 1996;6:460-466. [PubMed: 8794157]

2. Maneg O, Malatesta F, Ludwig B, Drosou V. Biochim Biophys. Acta 2004;1655:274-281. [PubMed: 15100042]

3. Carr HS, Winge DR. Acc. Chem. Res 2003;36:309-316. [PubMed: 12755640]

4. Cobine PA, Pierrel F, Winge DR. Biochim. Biophys. Acta 2006;1763:759-772. [PubMed: 16631971]

5. Banci L, et al. Proc. Natl. Acad. Sci. USA 2005;102:3994-3999. [PubMed: 15753304]

6. Khalimonchuk O, Winge DR. Biochim. Biophys. Acta 2008;1783:618-628. [PubMed: 18070608]

7. Banci L, Bertini I, Cavallaro G, Rosato A. J. Proteome Res 2007;6:1568-1579. [PubMed: 17300187]

8. Horng YC, et al. J. Biol. Chem 2005;280:34113-34122. [PubMed: 16091356]

9. McEwan AG, et al. FEBS Lett 2002;518:10-16. [PubMed: 11997009]

10. Andruzzi L, Nakano M, Nilges MJ, Blackburn NJ. J. Am. Chem. Soc 2005;127:16548-16558. [PubMed: 16305244]

11. Imriskova-Sosova I, et al. Biochemistry 2005;44:16949-16956. [PubMed: 16363808]

12. Banci L, et al. Proc. Natl. Acad. Sci. USA 2006;103:8595-8600. [PubMed: 16735468]

13. Williams JC, et al. J. Biol. Chem 2005;280:15202-15211. [PubMed: 15659396] 
14. Balatri E, Banci L, Bertini I, Cantini F, Ciofi-Baffoni S. Structure 2003;11:1431-1443. [PubMed: 14604533]

15. Ye Q, Imriskova-Sosova I, Hill BC, Jia Z. Biochemistry 2005;44:2934-2942. [PubMed: 15723536]

16. Abajian C, Rosenzweig AC. J. Biol. Inorg. Chem 2006;11:459-466. [PubMed: 16570183]

17. Bertini I, et al. J. Am. Chem. Soc 1996;118:11658-11659.

18. Arnesano F, Banci L, Bertini I, Martinelli M. J. Proteome Res 2005;4:63-70. [PubMed: 15707358]

19. Mattatall NR, Jazairi J, Hill BC. J. Biol. Chem 2000;275:28802-28809. [PubMed: 10837475]

20. Banci L, et al. Proc. Natl. Acad. Sci. USA 2007;104:15-20. [PubMed: 17182746]

21. Banci L, et al. Structure 2007;15:1132-1140. [PubMed: 17850752]

22. Banci L, et al. Proc. Natl. Acad. Sci. USA 2008;105:6803-6808. [PubMed: 18458339] 


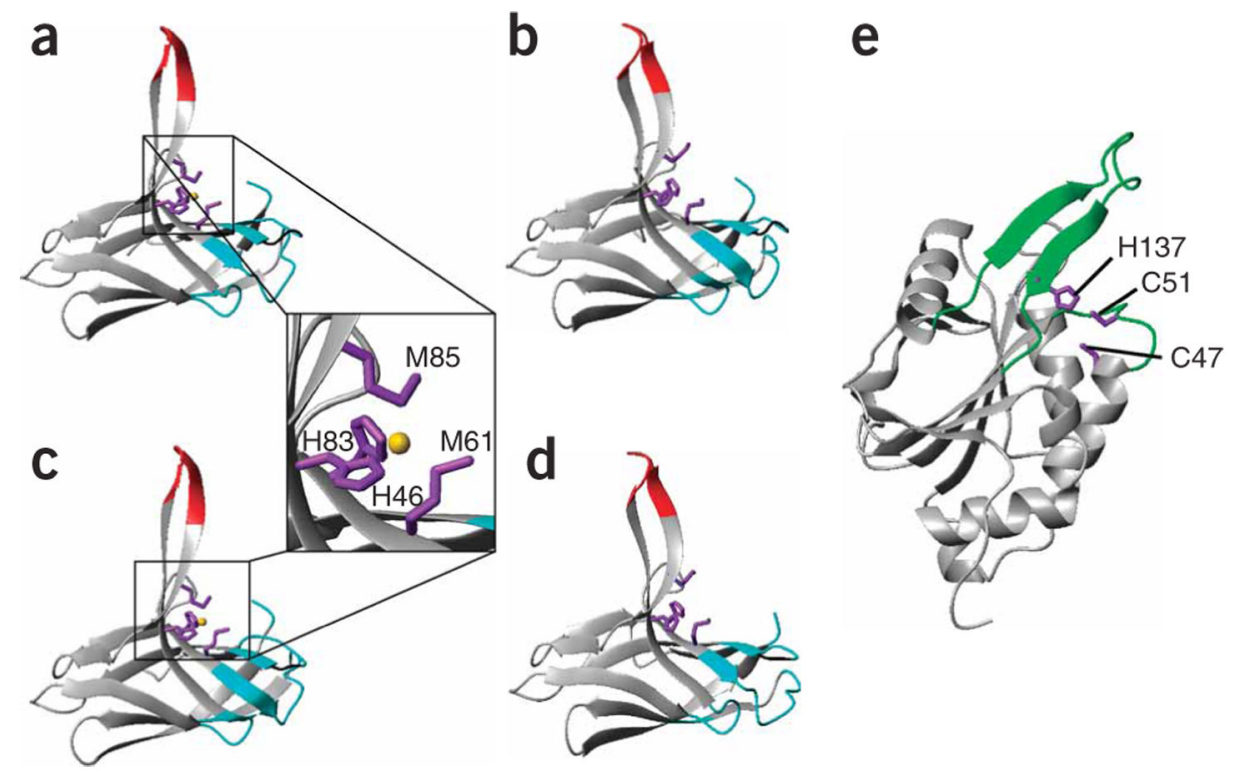

Figure 1. Solution structures of apo-Tt $\mathrm{PCu} \mathrm{A}_{\mathrm{A}} \mathrm{C}, \mathrm{Cu}(\mathrm{I})-T t \mathrm{PCu}_{\mathrm{A}} \mathrm{C}$ and apo-Tt Sco1 (a-d) The trans $(\mathbf{a}, \mathbf{b})$ and cis (c,d) conformations resulting from Pro14 isomerization in $T t$ $\mathrm{PCu}_{\mathrm{A}} \mathrm{C}$ are shown for each protein. The methionine and histidine residues that bind the metal are shown as purple sticks in $T t \mathrm{PCu}_{\mathrm{A}} \mathrm{C}$. The $\mathrm{Cu}(\mathrm{I})$ ion is rendered as a golden sphere. The inset highlights the metal binding site of $\mathrm{Cu}(\mathrm{I})-T t \mathrm{PCu}_{\mathrm{A}} \mathrm{C}$. Residues experiencing double conformations in $T t \mathrm{PCu}_{\mathrm{A}} \mathrm{C}$ as a consequence of cis-trans proline isomerization are shown in cyan, and those displaying fast backbone motions at $298 \mathrm{~K}$ are shown in red. (e) The metal ligands Cys47, Cys51 and His137 of apo-Tt Sco1 are shown as purple sticks, and loops 3 and 8 are shown in green. 
a

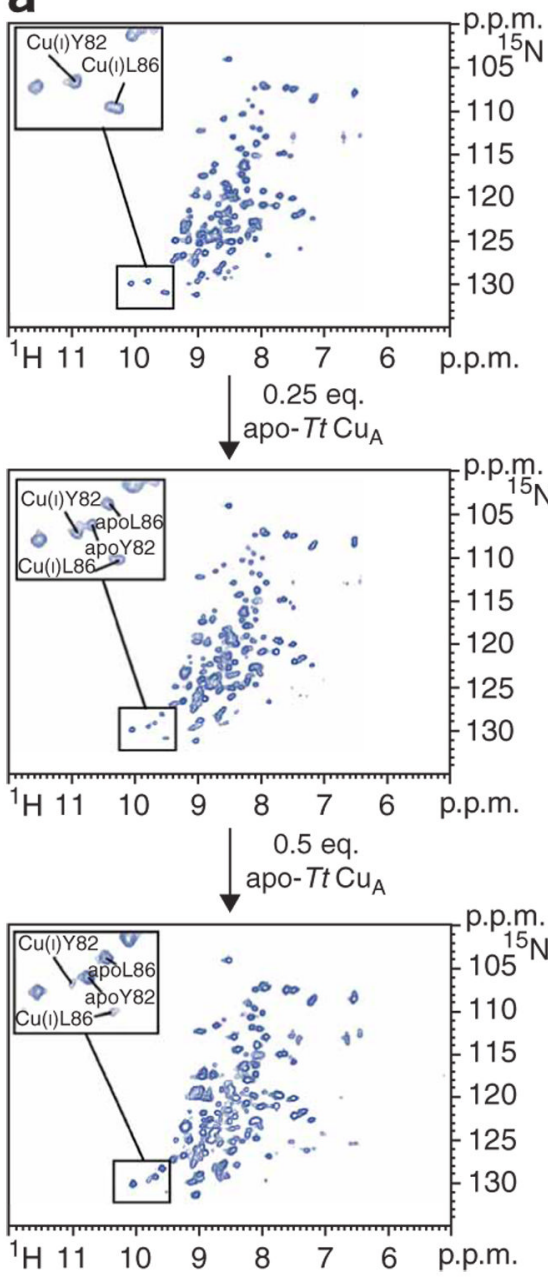

b

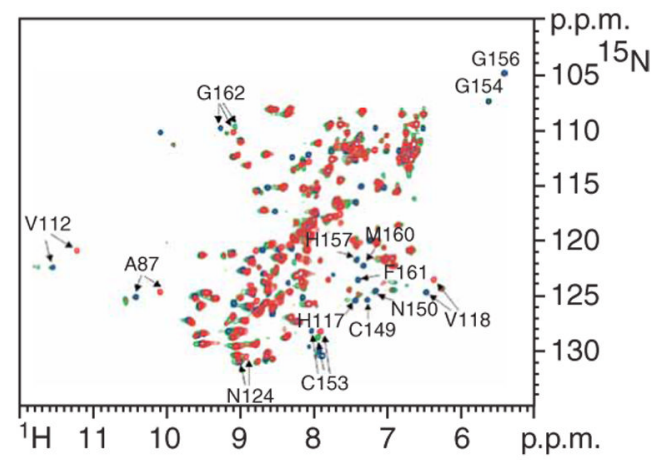

C

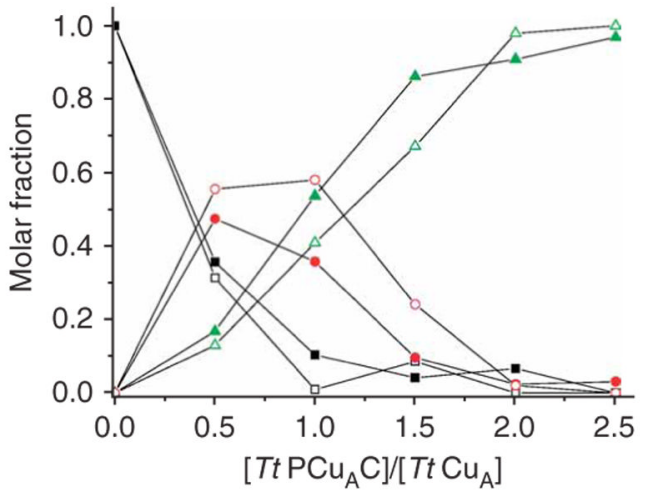

Figure 2. $\mathrm{Cu}(\mathrm{I})$ transfer reaction between $\mathrm{Cu}(\mathrm{I})-T t$ PCu $\mathrm{C}$ and apo-Tt $\mathrm{Cu}_{\mathrm{A}}$

(a) Titration of ${ }^{15} \mathrm{~N}$-labeled $\mathrm{Cu}(\mathrm{I})-T t \mathrm{PCu}_{\mathrm{A}} \mathrm{C}$ with unlabeled apo-Tt $\mathrm{Cu}_{\mathrm{A}}$ followed by ${ }^{1} \mathrm{H}_{-}{ }^{15} \mathrm{~N}$ HSQC experiments. In the insets, residues followed to map the metal exchange reaction are shown. (b) Overlay of the ${ }^{1} \mathrm{H}^{-15} \mathrm{~N}$ HSQC spectra of ${ }^{15} \mathrm{~N}$ apo- $T t \mathrm{Cu}_{\mathrm{A}}$ (red), and after addition of one (green) and two (blue) equivalents of unlabeled $\mathrm{Cu}(\mathrm{I})-T t \mathrm{PCu}_{\mathrm{A}} \mathrm{C}$. Some residues indicating the formation of $\mathrm{Cu}(\mathrm{I})_{2}-T t \mathrm{Cu}_{\mathrm{A}}$ and of a partially metallated $\mathrm{Cu}_{\mathrm{A}}$ species are labeled. (c) Plot showing the relative concentrations of $\mathrm{Cu}(\mathrm{I})_{2}-T t \mathrm{Cu}_{\mathrm{A}}$ (green), the partially metallated $\mathrm{Cu}_{\mathrm{A}}$ protein (red) and apo-Tt $\mathrm{Cu}_{\mathrm{A}}$ (black) as a function of the $T t \mathrm{PCu}_{\mathrm{A}} \mathrm{C} / T t \mathrm{Cu}_{\mathrm{A}}$ molar ratio. The signals of residues Cys153 (solid symbols) and Gly162 (open symbols) (whose ${ }^{1} \mathrm{H}^{-15} \mathrm{~N}$ chemical shifts substantially change depending on the metallation state of $\left.T t \mathrm{Cu}_{\mathrm{A}}\right)$ have been selected to evaluate the molar fractions of $T t \mathrm{Cu}_{\mathrm{A}}$ forms. 

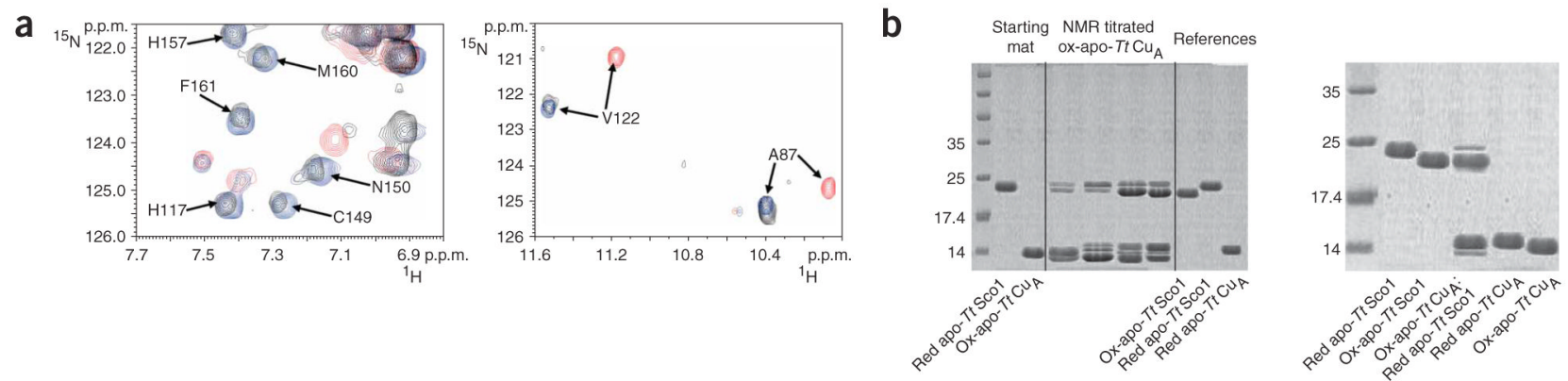

Figure 3. $\mathrm{Cu}(\mathrm{I})$ transfer from $\mathrm{Cu}(\mathrm{I})-\mathrm{Tt}$ PCu $\mathrm{A}$ to oxidized apo-Tt $\mathrm{Cu}_{\mathrm{A}}$ in the presence of reduced apo-Tt Sco1

(a) ${ }^{1} \mathrm{H}-{ }^{15} \mathrm{~N}$ HSQC overlay of oxidized apo-Tt $\mathrm{Cu}_{\mathrm{A}}$ (red), $\mathrm{Cu}(\mathrm{I})_{2}-T t \mathrm{Cu}_{\mathrm{A}}$ (blue) and the final mixture of the titration between ${ }^{15} \mathrm{~N}$-labeled oxidized apo- $T t \mathrm{Cu}_{\mathrm{A}}$ and unlabeled, reduced apoTt $\mathrm{Sco} 1$ and $\mathrm{Cu}(\mathrm{I})-T t \mathrm{PCu}_{\mathrm{A}} \mathrm{C}$ in a 1:1:2 ratio, in the absence of DTT (black). (b) Left panel: AMS-reacted, nonreducing SDS gel of different aliquots from the NMR titration between ${ }^{15} \mathrm{~N}$-labeled oxidized apo-Tt $\mathrm{Cu}_{\mathrm{A}}$ and a 1:2 mixture of unlabeled, reduced apo-Tt Sco1 and $\mathrm{Cu}(\mathrm{I})-T t \mathrm{PCu}_{\mathrm{A}} \mathrm{C}$ (shown in a). Four steps of the NMR titration are reported. The band of $T t \mathrm{Cu}_{\mathrm{A}}$ protein at $14.8 \mathrm{kDa}$ is very close to that of $T t \mathrm{PCu}_{\mathrm{A}} \mathrm{C}$, which indeed has a very similar molecular weight (13.2 kDa). Starting materials and the $T t \mathrm{PCu}_{\mathrm{A}} \mathrm{C}$ and $T t \mathrm{Cu}_{\mathrm{A}}$ proteins in their different redox states are also reported as a reference. Right panel: AMS-reacted, nonreducing SDS gel of a protein mixture containing oxidized apo- $T t \mathrm{Cu}_{\mathrm{A}}$ and reduced apo-Tt $\mathrm{Sco} 1$ in a 1:1 ratio. The proteins in their different redox states are also reported as a reference. Molecular weight markers are shown in first lanes. 